\title{
ROLE OF STAKEHOLDERS IN PRESERVING BIODIVERSITY IN BANGLADESH: A STUDY ON TANGUAR HAOR
}

\author{
Dr. Esmat Ara \\ Associate Professor, Department of Public Administration \\ Shahjalal University of Science \& Technology, Sylhet, Bangladesh \\ Shah Md. Ziaul Islam \\ MSS Final year Student, Department of Public Administration \\ Shahjalal University of Science \& Technology, Sylhet, Bangladesh
}

\begin{abstract}
Tanguar Haor, the most diversified ecosystem of Bangladesh is important for surviving around 70,000 people. Tanguar Haor has been declared ecologically critical area for 20 years. This study aims to examine the role of relevant stakeholders in conserving the countries' second RAMSAR site. This paper also attempted to understand the causes of loss of biodiversity of Tanguar Haor as well as its solution. Mixed methods (qualitative and quantitative) research has employed for this study applying purposive sampling strategy. Study findings reveal that indiscriminate harvesting of mother fishes, use of agrochemicals, deforestation, hunting migratory birds, increasing trace metal, mixing silt soil with water are the major contributor to loss of biodiversity in Tanguar Haor. With the support of the Swedish Development Corporation (SDC) and International Union for Conservation of Nature (IUCN), the government of Bangladesh has conducted a big budgeted project to preserve biodiversity of Tanguar Haor, however there found lack of coordination among peoples' representatives, government agencies, and IUCN. Hence, the study findings will hopefully contribute to identify the irregularities in performing the role of different stakeholders that will lead taking further initiatives to preserve biodiversity of Tanguar Haor in Bangladesh.
\end{abstract}

Keywords: Stakeholders, Role, Preserving, Biodiversity, Tanguar Haor, Bangladesh.

Cite this Article: Dr. Esmat Ara and Shah Md. Ziaul Islam, Role of Stakeholders in Preserving Biodiversity in Bangladesh: A Study on Tanguar Haor, International Journal of Management, 10 (2), 2019, pp. 17-38.

$\mathrm{http}: / /$ iaeme.com/Home/issue/IJM?Volume $=10 \&$ Issue $=2$ 


\section{INTRODUCTION}

Wetlands are the most productive ecosystems in the earth. Wetlands provide extensive food webs and rich biodiversity which is essential for balanced environment and sustainable development. Natural wetland also provide many services toward mankind through various functions, products, fish, fuelwood, timber, rice, aesthetic beauty, cultural heritage and archaeology. Geographically Bangladesh is known as the land of wetlands and more than twothirds of the country may be classified as wetlands. Wetlands ecosystems are rich in biodiversity and great importance to Bangladesh because of their critical economic and ecological role in sustaining life and livelihoods of communities living in close propinquity to the area (Uddin, Miah, Afrad, Mehraj, \& Mandal, 2015). Bangladesh's most important freshwater wetlands occur in the Hoar Basin apart from the Ganges, Brahmaputra delta, which is low lying plains in eastern Mymensingh and western Sylhet Divisions, in the north-eastern part of the country (Rahman, Sharker, Sumi, Alam, \& Hossen, 2014). Tanguar Haor is located in two Upazillas (sub-districts) namely Tahirpur and Dharmapasha of Sunamganj district in Sylhet Division. The Tanguar Haor basin, which is an area of 10,000 hectares of land, also supports about 60,000 populations with its resources (Alam, Chowdhury \& Sobhan, 2012). TanguarHaor is the home of 140 species of sweet water fishes and thousands of indigenous birds. It is also an excellent wintering site for large numbers of migratory birds. This Haor also is a harbour of non-fish organisms like snails, mussels and different types of aquatic vegetation. There is a great importance of TanguarHaor in fish Production, maintaining biodiversity, meeting local demand and regional demand and also serve as the good source of fish seed supply for other water bodies (Chowdhury, 2008). The Government has declared TanguarHaor as an Ecologically Critical Area (ECA) in 1999 considering its critical condition due to overexploitation of natural resource. In 2000, the Hoar basin was also declared as the country's second Ramsar site wetland of international importance (SDC). Tanguar Haor is considered as a refuge for threatened fish and is also home to some of a bigger species (IUCN, 2008). With the declaration of Tanguar Haor as a RAMSAR site, government has its commitment to preserve the ecosystem and floral and faunal diversity including its migratory birds from illegal hunters. Government developed a comprehensive management plan-the Tanguar Haor Management Plan (THMP). Later, the government in collusion with NGO took a number of initiatives to protect the bio diversity of Tanguar Haor. At present, over catching of fisheries, hunting migratory birds, cutting trees are common scenario.

\section{STATEMENT OF THE PROBLEM}

Bangladesh is biologically very diverse country. Its geographical location, deltaic structure, and sub-tropical climate have made it a home of about 4,200 plant species (from angiosperms to mosses) in its evergreen, semi-evergreen and deciduous forests on the hills and plain lands; in mangroves; and in numerous rivers and wetlands.

Tanguar Haor is one of the most important wetlands not only of Bangladesh but also of South Asia (Bird Life International, 2012). It is a unique wetland ecosystem in Bangladesh and has now gained international focus. The Government of Bangladesh declared Tanguar Haor as an Ecologically Critical Area in 1999 considering its critical condition as a result of overexploitation of its natural resources and declared as a Ramsar site in 2000 (GoB, 2004). The rich biodiversity, notable occurrence of wildlife especially waterfowl is one of the most significant features that allowed this area to gain the designation as a Ramsar site. Tanguar Haor is also extremely rich in terms of fisheries resources that play a critical role in Bangladesh's economy. However, almost every water bodies and wetlands of Bangladesh is under threat. Huge population pressure, climate change impact, development interactions, disappearing, pollution, over harvesting of the natural resources, land use conflict, lack of upstream water 
flow in winter, and increase risk of flood are the major threats to wetland (Chakraborty, 2009). During early 1990s, environmentalists raised a demand to conserve eight endangered sites of the country including TanguarHaor, following which the government undertook a 10-year project with the cooperation of International Union for Conservation of Nature (IUCN) with an allocation of USD \$ 7,467,570 in first phase. District Administration abrogated the lease system and handed over authority to protect the Haor to the IUCN in 2006. The IUCN itself puts it somewhat differently with support from the Swiss Agency for Development and Cooperation (SADC). IUCN managed Tanguar Haor together with the Government of Bangladesh and local communities. However, the protection and management status of wetlands in Bangladesh is more complex and severe due to financial, technical, social, and political decision, as well as lack of integration of those sectors (Islam, S 2010). Furthermore, many alleged that since the IUCN took over, cutting down trees illegally has increased due to lack of supervision. Catching rare fish species illegally increased that time, that biodiversity of Tanguar Haor is in danger at present time. After completion of IUCN project, no research conducted to understand real scenario of maintenance of Tanguar Haor. It is necessary to conduct a research to examine the role stakeholders in preserving biodiversity of Tanguar Haor.

\section{PURPOSE AND SIGNIFICANCE OF THE STUDY}

The main purpose of this study is to find out the role of multi-stakeholders in preserving biodiversity of TanguarHaor, a world heritage. The study also tried to identify the challenges of preserving biodiversity along with some measures to promote biodiversity of Tanguar Haor in Bangladesh. TanguarHaor is known as sanctuary of biodiversity. It contains thousands of species of sweet water fisheries, birds, insects, trees etc. 'Tanguar Haor provides habitat for at least 135 fish and 208 bird species, including 92 water bird species and 98 migratory bird species, and including 10 IUCN Red Book and 22 CITES listed species. About 30-40,000 migratory waterfowl converge on the area in the northern winter months, according to the site's Ramsar listing. Where varieties of plants like Hijol, Karach, Nalkhagra, Chaliabaan, and many others sprouted abundantly, turning it into a famed sanctuary for the migratory birds, today a group is behind massive deforestation in TanguarHaor flouting regulations.

Their destructive activities are not only hampering the aesthetic beauty of the Haor - they are directly playing havoc with its priceless biodiversity (The Daily Star, August 08, 2017). TanguarHaor declared second RAMSAR site of Bangladesh, is particularly threatened by over exploitation of fishery stocks, deforestation and large scale waterfowl harvesting. The area has so far been ruled by wealthy and politically well-connected people for a long period, and the local fishermen have been excluded from this resource which has led to significant impoverishment.

Besides these, TanguarHaor is losing its biodiversity for many other reasons. Generally tourism opens the door of economic activity that brings prosperity and affluence among the stakeholders. But in the case of TanguarHaor, tourism affects the ecosystem of wetland planet. Recently a number of tourists travel to TanguarHaor and enjoy the beauty of the nature. Travellers have been passing night in Haor and throw the packet of chips and other foods on the Haor that seriously hamper the ecosystem of fisheries and planet. They torch towards the eye of migratory birds that contribute to loss of biodiversity. Considering the issues it is urgently needed to study about the causes of loss of biodiversity and role government and other stakeholders in preserving biodiversity in the country's second Ramsar site. A comprehensive analytical analysis of the various issues leading to wetlands degradation is made in this study that will help to provide a direction for Bangladesh government adopting adequate interdisciplinary policy guideline and political wills to implement them for sustainable management and protection of wetlands, and ecologically sensitive sites. 


\section{LITERATURE REVIEW}

Indiscriminate harvest of mother fishes was identified as a major cause of fish declination. Besides this, corruption, illegal fishing, use of agrochemicals and habitat destruction were also found as reasons for the reduction of fish species in the study area. Fisheries resource declination results loss of biodiversity in TanguarHaor (Mamun et al., 2012). Wetland ecosystems are of great importance to Bangladesh because of their extent and of the critical economic and ecological role that they play in sustaining life and livelihoods in the country (Islam, 2010). Wetlands provide short and long-term benefits and services to the people of Bangladesh including crop and fish production, swamp forest and reed land maintenance, and regulation of water flow (Chowdhury, 2009). There is considerable change due to flash flood in Haor basin, which destroys thousand hector of rice crop with agricultural land. Due to the flash flood, food crisis arises around the Haor basin livelihood (Khan, Mia, \& Hossain, 2012). When this sort of crisis situation arises then the local people harvest the fisheries and cutting swamp forest for their sustentation which are the main elements of biodiversity in TanguarHaor (Hossain et al, 2017).

Biodiversity monitoring technique namely 'Community based Biodiversity Monitoring' that will be used by the groups consisting of experts, project staff and local volunteers such as committee members, school teachers or students from colleges and schools. Enthusiastic people from local community having interest in biodiversity conservation will be selected as 'local volunteers' (Singh, P. P. (2008). Central Committee with help of management authority will select the local volunteers. A biodiversity monitoring team would be formed with above mentioned people. Four monitoring teams would be formed and they would work in four unions. The Swamp forests that once used to be common in TanguarHaor have now become very rare due to clearing, cutting and other anthropological activities, and the last vestiges of it remains in area called Ronchi. Sweet water fishes are in great trouble because of catching fish illegally (Alam et al., 2012). People of Tanguar Haor are mostly dependent on fisheries resources to a great extent. Fishing is the most important economic activity of the TanguarHaor dependent people (Rahaman, Sajib, \& Alam, 2016). More than $70 \%$ of households involved in fisheries activities either for income or for food. They also mentioned that the local people perceive the gradual degradation of the resources, especially over-harvesting of fishery resources by the hired fisher folks (Mondal et al., 2010).

There is a great importance of coordination between various governmental agencies and Non-Government Organizations to protect wetlands and ecosystems. Due to lack of coordination between governmental agencies and NGOs many project and policies did not see the light of success (Azhar, 2014). Bangladesh has been achieving community-based sustainable use of wetland resources. They emphasize on implementing government initiatives properly and make the wetland free from politics. Bangladesh conducted a number of highly budgeted projects to keep the biodiversity of wetland balance (Khan et al 2000). A study was conducted on Poverty, equity and rights in conservation. This case study focused on ensuring sustainable development and livelihoods of rural people in South Asia where Tanguar Haor was one of the study sites. In Tanguar Haor, resource rights could be a potential aspect to ensure sustainable livelihoods, environmental security and to mitigate conflict in the Haor areas (Oviedo et al., 2005).

Tanguar Haor is one of the remote places of Bangladesh. Consequently, living in Tanguar is also very energetic. Materials for making houses in Tanguar, generally come from the Haor itself. The swamp forest supplied the structure of their houses, so over the time, these sources became scarce as the natural resources are destroying day by day (Haque, \& Basak, 2017). The people, living in TanguarHaor are highly dependent on the Haor ecosystem for their income. Most of their income is either directly or indirectly derived from the Haor. Farming, fishing, 
fish trading, and boating activities are the major occupation of Haor people (Haque and Haque, 2008). Community Based Sustainable Management of Tanguar Haor Project has made some notable efforts in habitat restoration and biodiversity conservation. Four fish reservations have been established in the core area. Besides, five Beels were protected by piling with bamboo and planting native tree to protect the fish habitat against poaching. Forestation initiatives also have taken to preserve biodiversity of Tanguar Haor (Azhar, 2014).

A good number of research works have been conducted on different arena of Tanguar Haor, like causes of fisheries resource declination, wetland biodiversity conservation, harvest of fisheries in Tanguar Haor, and present status of biodiversity in Taguar Haor, but there is very few research conducted regarding role of government and other stakeholders in preserving biodiversity of Tanguar Haor.

\section{CONCEPTUAL FRAMEWORK}

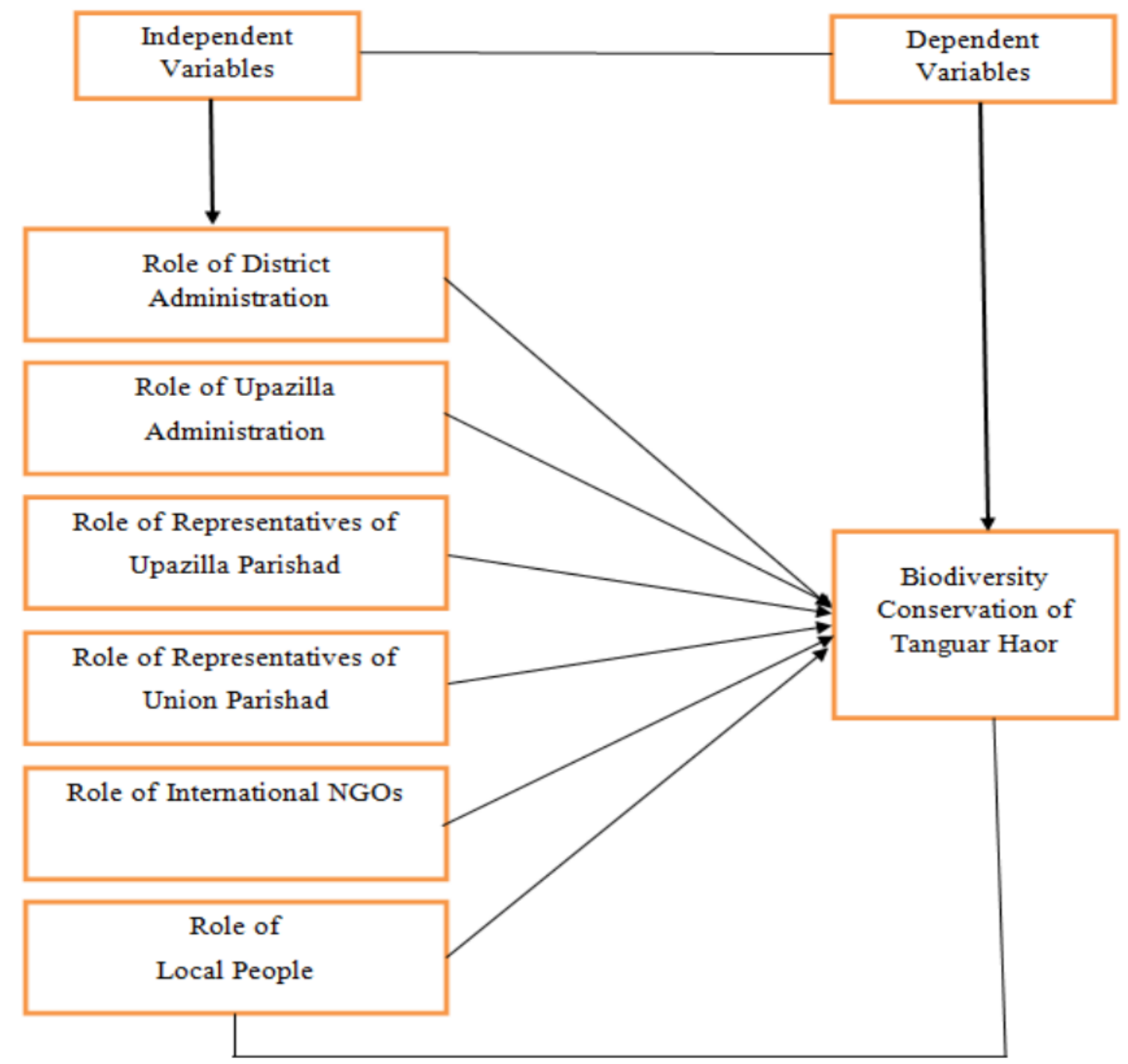

Figure 1: Conceptual framework

The conceptual framework presents the relationship between the dependent and independent variables. In this part of research, different variables are identified. There are two types of variables: Independent variable and Dependent variable. 
Independent variable means such variables that influence other variable. In this research possible independent variables are the role of multi-stakeholders in preserving biodiversity of Tanguar Haor. Dependent variable is that which resulted from the function of the independent variables. Their interrelationship and interdependency can be shown through the following chart.

Through this diagram, there is shown a cause-effect relationship between the dependent and independent variables. If the concerned stakeholders play appropriate role then the biodiversity of TanguarHaor will be preserved. Responsible role of district administration, Upazilla administration, local government representatives, Non-Government Organization (NGO) and local people can help to protect and conserve the biodiversity of TanguarHaor. So, role of district administration, Upazilla administration, local government representatives, NonGovernment Organization (NGO) and local people are the independent variables of the study.

\section{RESEARCH METHODOLOGY AND METHODS}

Both exploratory and explanatory research approaches have been employed in this study. Because exploratory research typically occurs when a researcher examines a new interest or when the subject of study itself is relatively new' (Babbie, 2004). Advantages of exploratory research are flexibility and adaptability to change. This implies that this form of qualitative research has an iterative nature in which preliminary data analysis coincides with data collection often results in altering questions as the researcher learns more about the subject (DiCiccoBloom \& Crabtree, 2006). On the other hand explanatory research is conducted to investigate or find out some problems that are not studied in detail. Descriptive research answers questions of what, where, when and how; explanatory questions, of why (Babbie, 2004). It is also necessary because only qualitative research or quantitative research is not sufficient to fully understand and the problem and strengths of one method can be used to overcome the weaknesses of another method (Creswell, 2003).

Mixed methods (both qualitative and quantitative) have been employed in this study. In this study, respondents have been selected purposively and accidentally. Qualitative research approach has been used in this study because qualitative research is the systematic inquiry into social phenomena in natural settings. These phenomena can include, but are not limited to, how people experience aspects of their lives, how individuals and/or groups behave, how organizations function, and how interactions shape relationships (Bogdan \& Biklen, 2006). And quantitative research approach provides opportunities to have a statistical analysis and justify the hypothesis properly. The researcher has taken the opportunity of cross-checking the data collected from the field. A purposive sample is a non-probability sample that is selected based on characteristics of a population and the objective of the study. Purposive sampling is also known as judgmental, selective, or subjective sampling. Accidental sampling is, as the name implies, a sample you chance upon by accident. The sample is convenient or available to you for some reason. In this study, 3 officials from district administration, 1 official from Upazilla administration, 8 local government representatives, 4 officials from International NGOs and 14 local peoples have been selected as sample.

TanguarHaor has been selected as study area. TanguarHaor is located in Sunamgonj district (Tahirpur and Dharmapasha Upazilla) covering an area of 9,727 hectares. Geographical position of is at $25^{\circ} 06^{\mathrm{ec}}$ to $25^{\circ} 11^{\mathrm{ee}} \mathrm{N}$ and $91^{\circ} 01^{\mathrm{ec}}$ to $91^{\circ} 06^{\mathrm{ee}} \mathrm{E}$. This site is influenced by Dhanu, Baulai, Surma and Jadukata Rivers.

Meghalaya hills are in the North from where number of streams flows to the Haor. Other important Haor like Matian, Shanir, and Thapner are very nearby and have some dependency with some degree of variation (Islam 2008). 


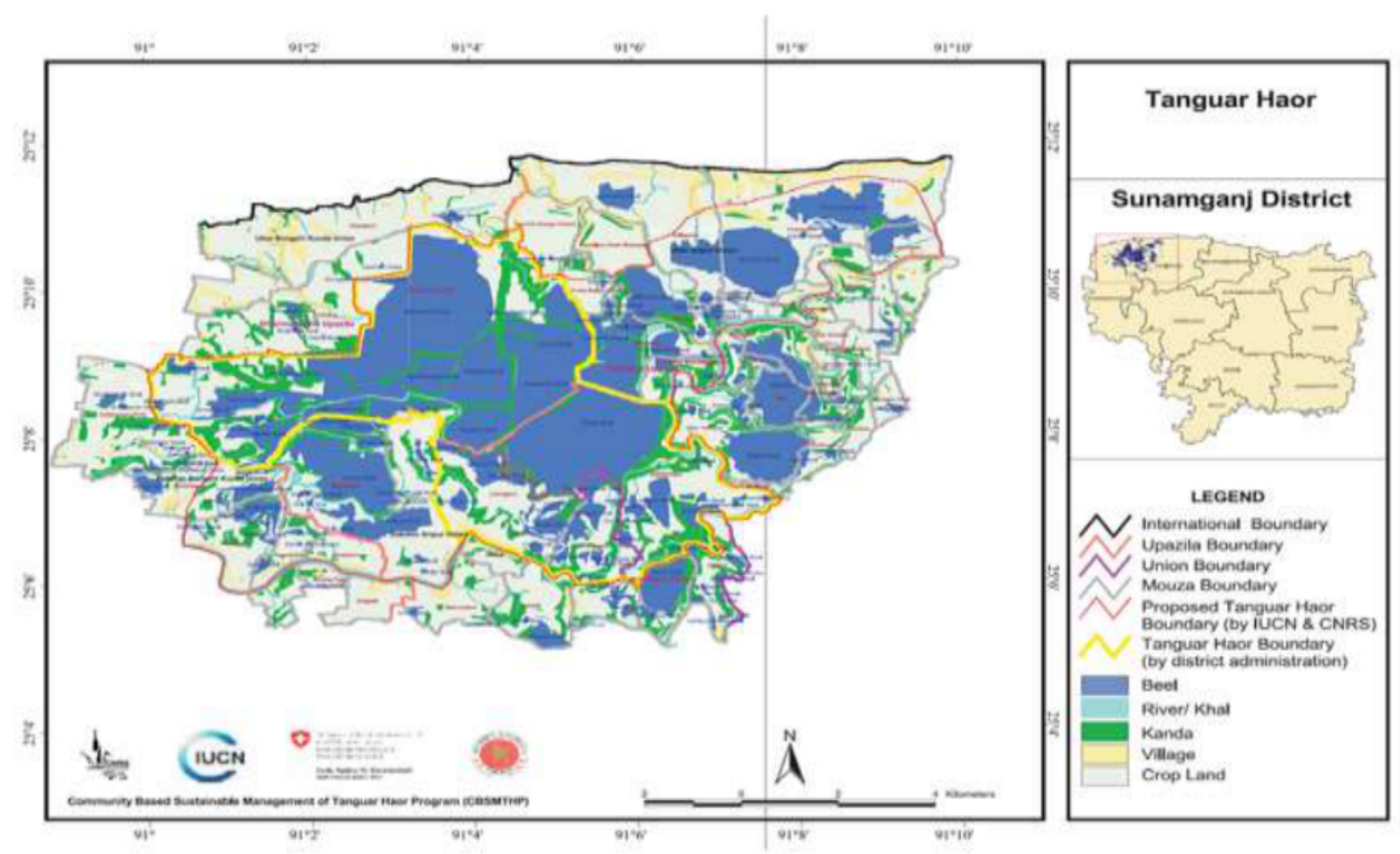

Figure 2: Tanguar Haor

The information has been collected through face to face interview with semi-structured interview schedule. Both open ended and closed ended questions have been selected for data collection. Secondary data have been collected from journals, articles, report of different organizations, newspapers, e-books which are related to the study. The quantitative data have been analysed using Statistical Package for the social science (SPSS). Thematic analysis method has been used in qualitative research and focuses on examining themes within data. This method emphasizes organize and rich description of data set. Thematic analysis is a systematic approach to the analysis of qualitative data that involves identifying themes or patterns (Lapadat, 2010).

\subsection{Data Presentation and Analysis}

The study has been conducted on the basis of qualitative and quantitative analysis. For the illustration of quantitative data, the study would like to present the data on invariant demographic data presentation method by using Statistical Programme for Social Science (SPSS) software to get reliable combination of data. On the other hand, for the analysis of qualitative data, thematic analysis has been used to analyse the data. Thematic analysis has been used because it is now a very simple way to analyse the data by identifying the themes from the data.

\subsection{Demographic Information of the Respondents}

In my study, most of respondents are between 26-35 years old. Minimum age limit is from 15 years to 25 years. Maximum age level of respondents is 55 years or more. This study tried to cover the perception of peoples at different level of age and experiences. Aged people shared lot of experiences regarding Tanguar Haor while young respondents shared recent activities of government and other stakeholders on Tanguar Haor. This study covered both male and female respondents to collect data. Most of the respondents were male ( 80 percent) while only 20 percent respondents were female. Reason behind not covering more female respondents is that 
females are not directly involved in destroying biodiversity of Tanguar Haor but they are involved in protecting biodiversity.

The sampling percentage of the total 30 respondents represent that $13.33 \%$ respondents are taken from bureaucrats, $13.33 \%$ respondents are taken from international NGOs while $26.67 \%$ respondents from local government representatives and rest $46.67 \%$ respondents are taken from local peoples.

\section{DATA PRESENTATION AND ANALYSIS (QUANTITATIVE)}

Chart 1 Whether Biodiversity of Tanguar Haor is on Threat

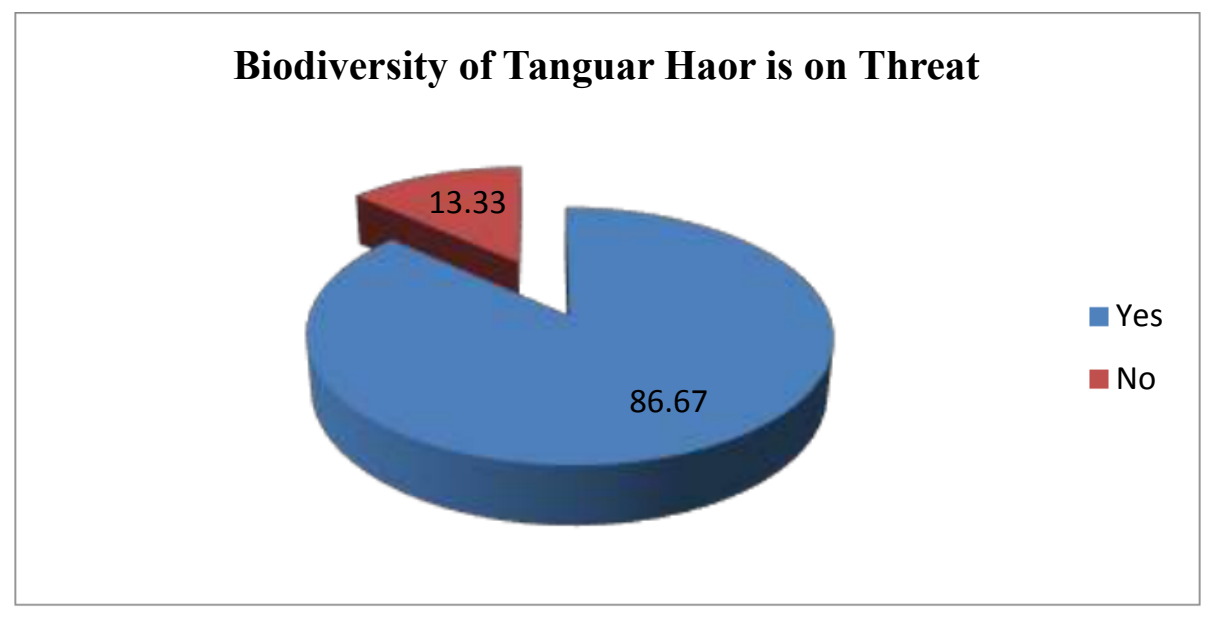

Figure 1

(Source: Field data)

This pie diagram shows that about 86.67 percent respondents believe that biodiversity of TanguarHaor is on threat. Only 13.33 percent respondents do not believe on above statement. So, by this diagram it can be said that necessary measure should be taken as most of the stakeholders believe that biodiversity of TanguarHaor is on threat.

Chart 2 Root Cause of Loss of Biodiversity in TanguarHaor

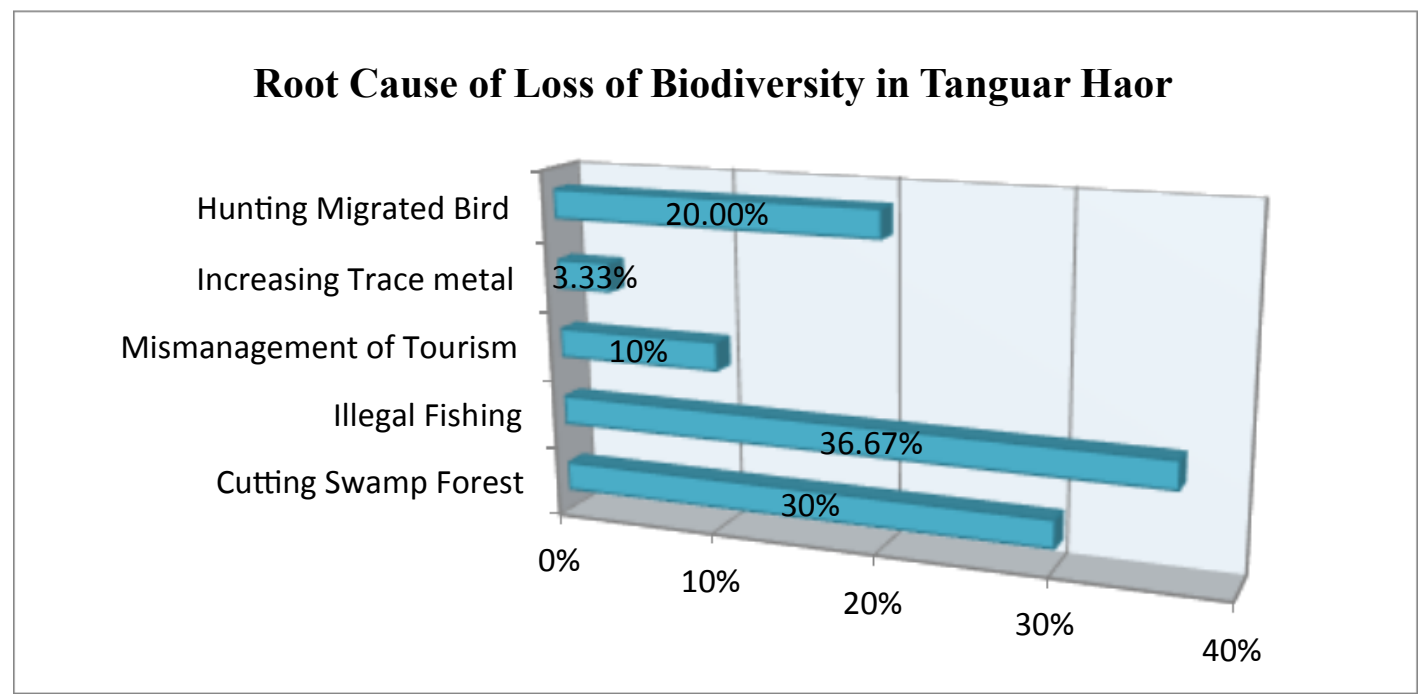

Figure 2

Source: Field Data 
A number of factors have been contributed in loss of biodiversity of TanguarHaor. Cutting swamp forest, illegal fishing, mismanagement of tourism, increasing trace metal, hunting migratory bird, mixing silt soil with wetland water etc. have been contributed in loss of biodiversity. Above bar chart shows that 36.67 percent respondents believe that illegal fishing is the root cause of loss of biodiversity while 30 percent respondents believe that cutting swamp forest is the root cause of loss of biodiversity in TanguarHaor. About 20 percent believe hunting migratory bird, 10 percent believe mismanagement of tourism and rest 3.33 percent believe increasing trace metal are the root cause of loss biodiversity of Tanguar Haor.

Chart 3 Root Cause of Destroying Swamp Forest and Illegal Fishing

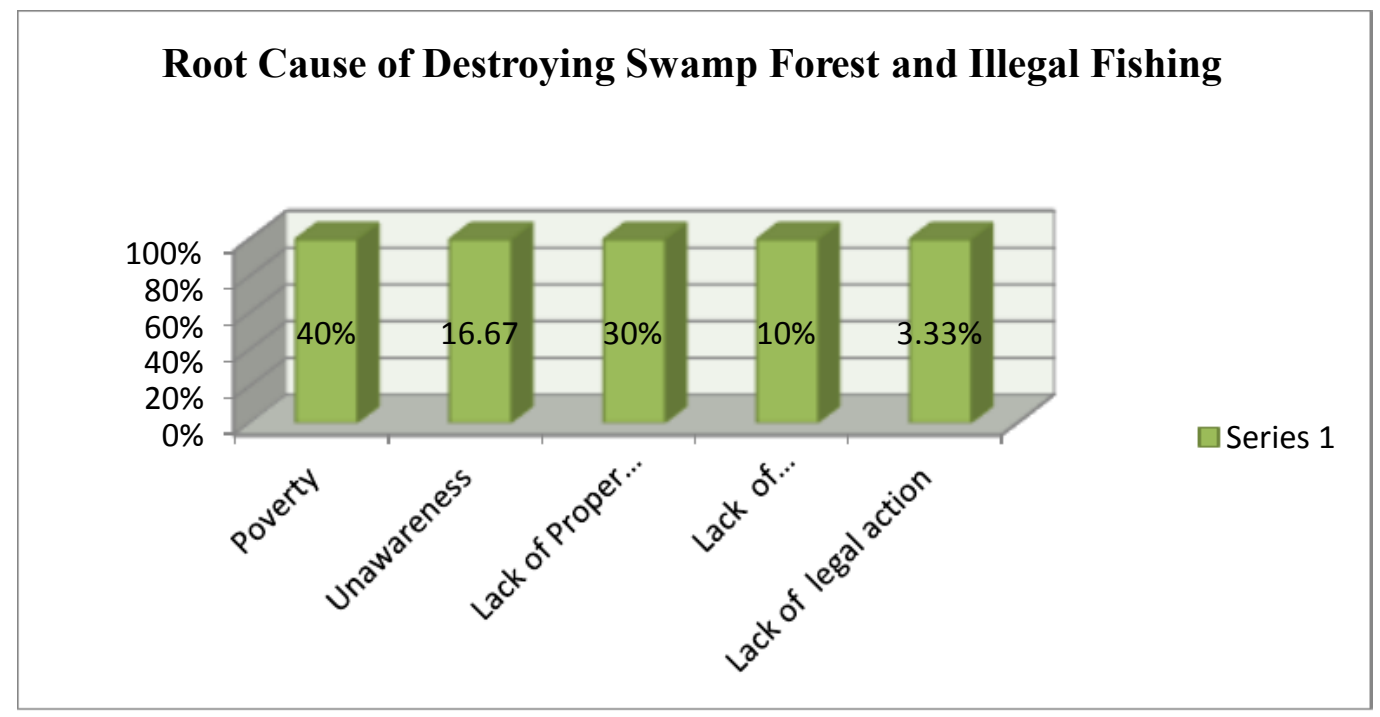

Figure 3

Source: Field Data

A number of factors are responsible for destroying swamp forest and illegal fishing in TanguarHaor. According to above line diagram, 40 percent respondent believe that poverty is considered as the root cause of destroying swamp forest and illegal fishing while 30 percent respondent believe that swamp forest is destroying due to lack of proper monitoring. 10 percent respondent believe that lack of proper maintenance and rest 3.33 percent believe that lack of legal action people have been destroying swamp forest and involving illegal fishing.

Chart 4: Environment Friendly Employment

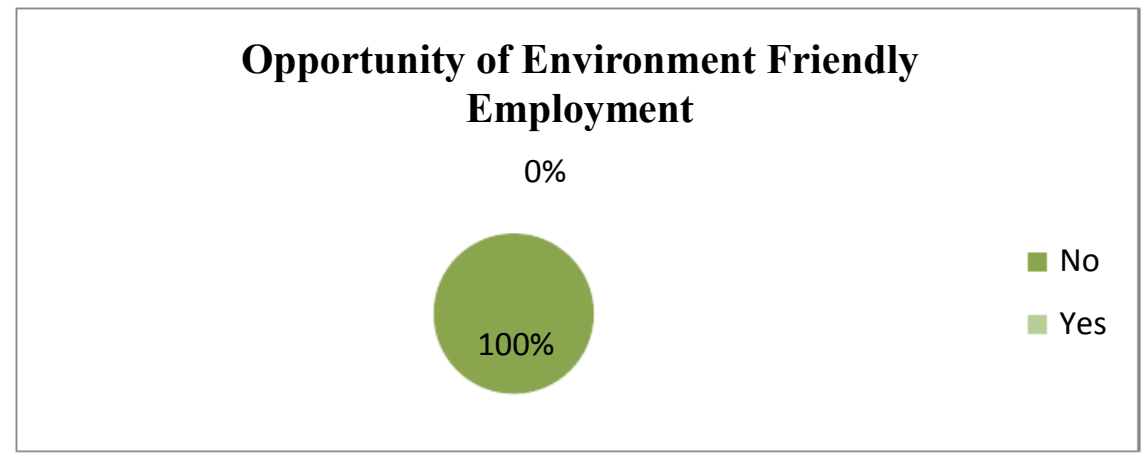

Figure 4

Source: Field Data 
Most of the people in TanguarHaor area are highly dependent on nature. Some of them are fisherman, some are involved in cultivation and few people are boatmen. When natural disaster attack on Haor area, the peoples are compelled to involve forbidden activities like illegal fishing, hunting migratory birds, deforestation etc. only for subsistence. The above pie chart shows that hundred percent $(100 \%)$ people agreed the statement that there is no opportunity to involve environment friendly occupation.

Chart 5: Over Crowd of Tourists and Mismanagement Hampers Biodiversity

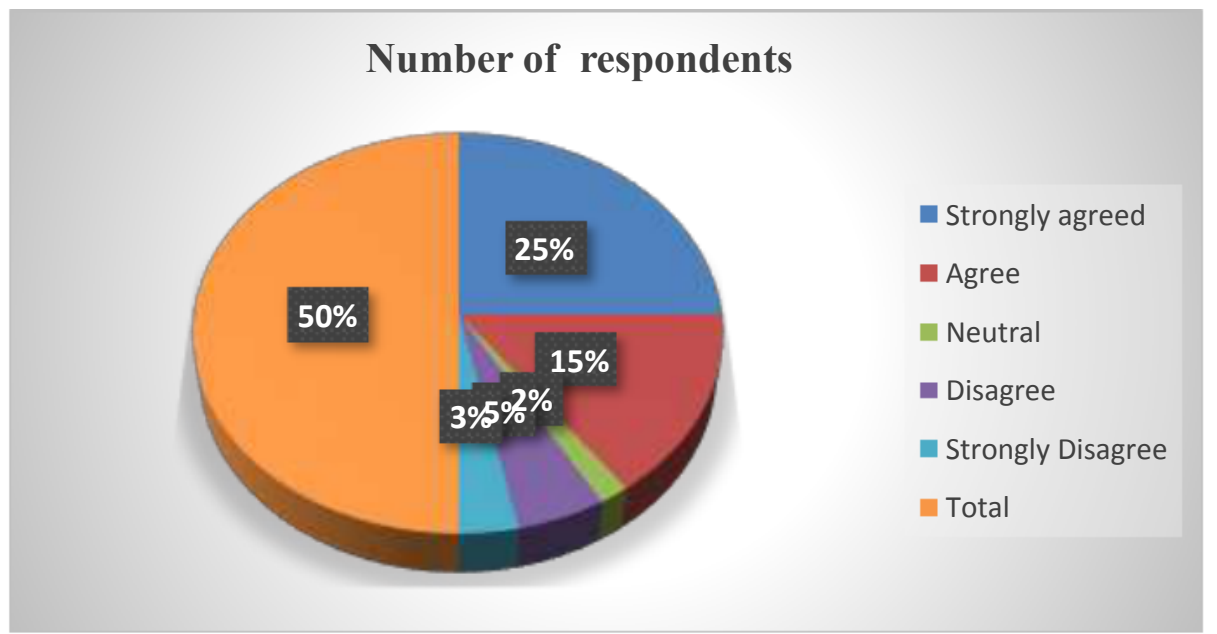

Figure 5

(Source: Field data)

Tourism opens the door of earning more revenue from TanguarHaor. The tourists have shown great interest in TanguarHaor to enjoy the natural beauty. But recently over crowd of tourists and mismanagement hamper the biodiversity and ecosystem of aquatic animals of TanguarHaor. 50.00 percent of the respondents agreed with the statement that over crowd of tourists and mismanagement hampers the biodiversity of TanguarHaor. 30.00 percent of the respondents agreed while 10 percent disagreed and 6.67 percent strongly disagreed with the statement.

Chart 6: Conservation of TanguarHaor and Spreading Haor Based Tourism

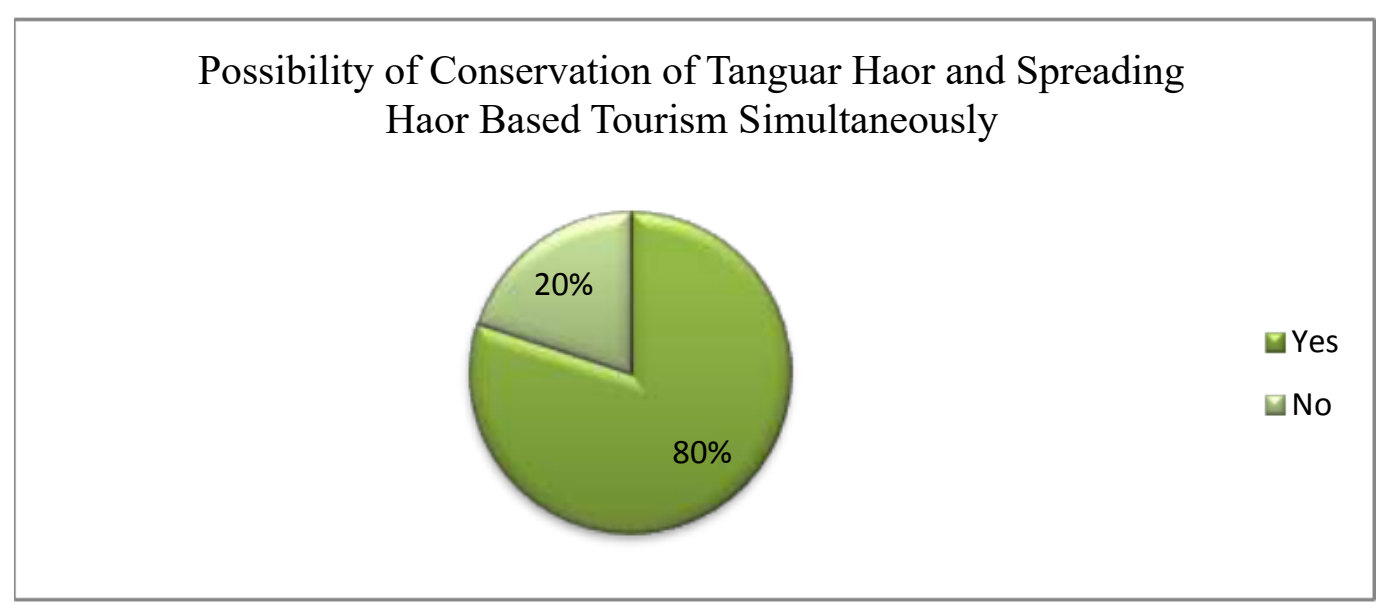

Figure 6

Source: Field Data 
Often tourism hampers natural ecosystem of aquatic animals and it can cause of loss of biodiversity in TanguarHaor. Above pie diagram shows, 80 percent respondent believe that conservation of TanguarHaor and spreading Haor based tourism industry simultaneously is possible while rest 20 percent respondent do not believe with above statement.

Chart 7: Disciplinary Action Taken by Administration

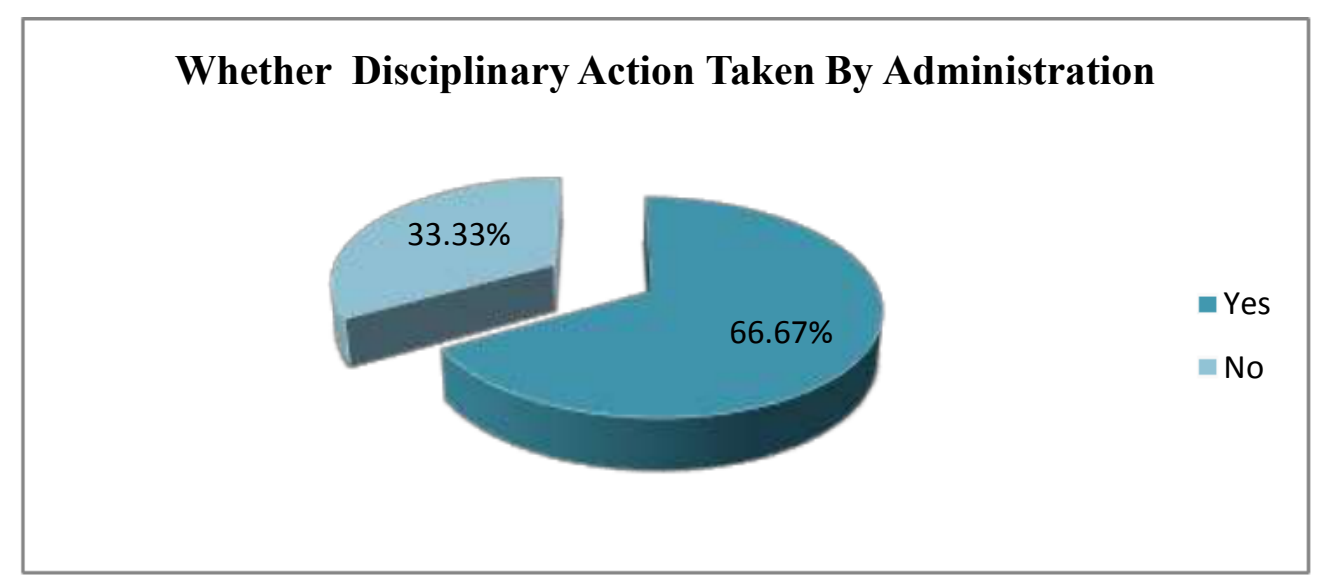

Figure 7

Source: Field Data

Above pie diagram shows, about 66.67 percent respondent agreed that administrative authorities take disciplinary action when any offence conducted by any offenders like illegal fishing, hunting migratory birds etc. Rest 33.33 percent believed that administrative authorities do not take disciplinary action against any offenders.

Figure 8: Influence of People's Representatives

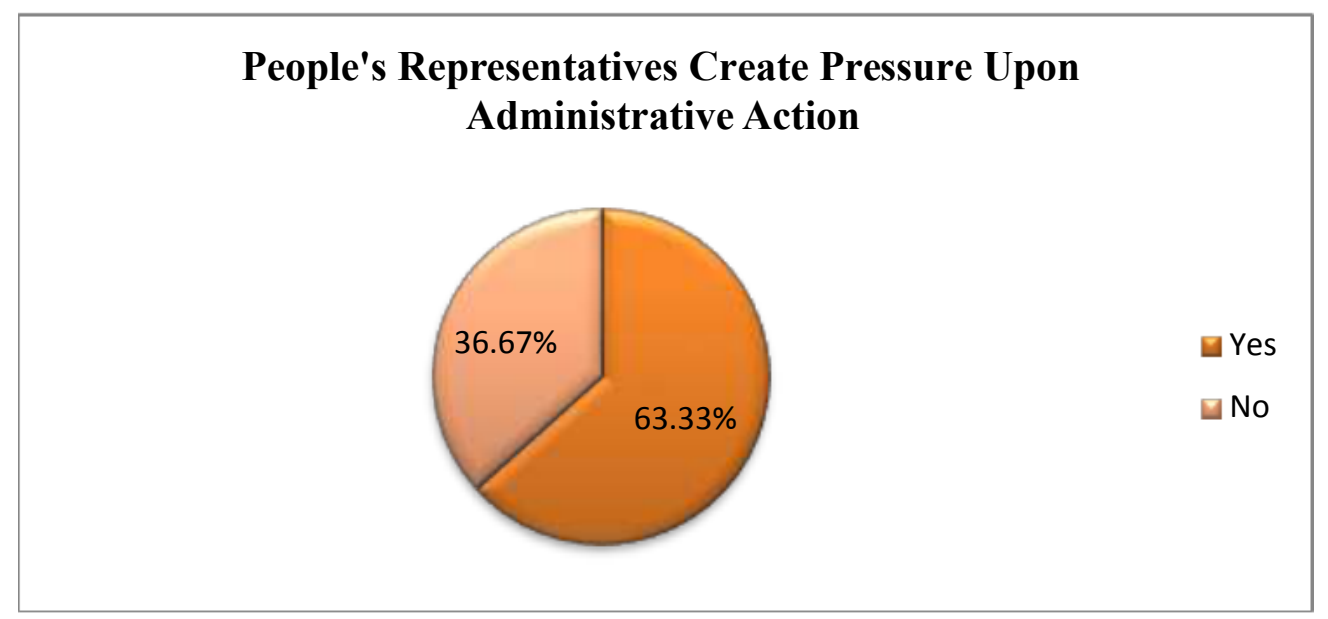

Figure 8

Source: Field Data

This pie diagram shows that 63.33 percent respondent believe that peoples' representatives create pressure upon administrative authorities when disciplinary action is taken against any offender. But rest 36.67 percent respondents believe that administrative authorities can take action freely and without interference of other

Figure 9: Decreasing the Rate of Hunting Migratory Birds 


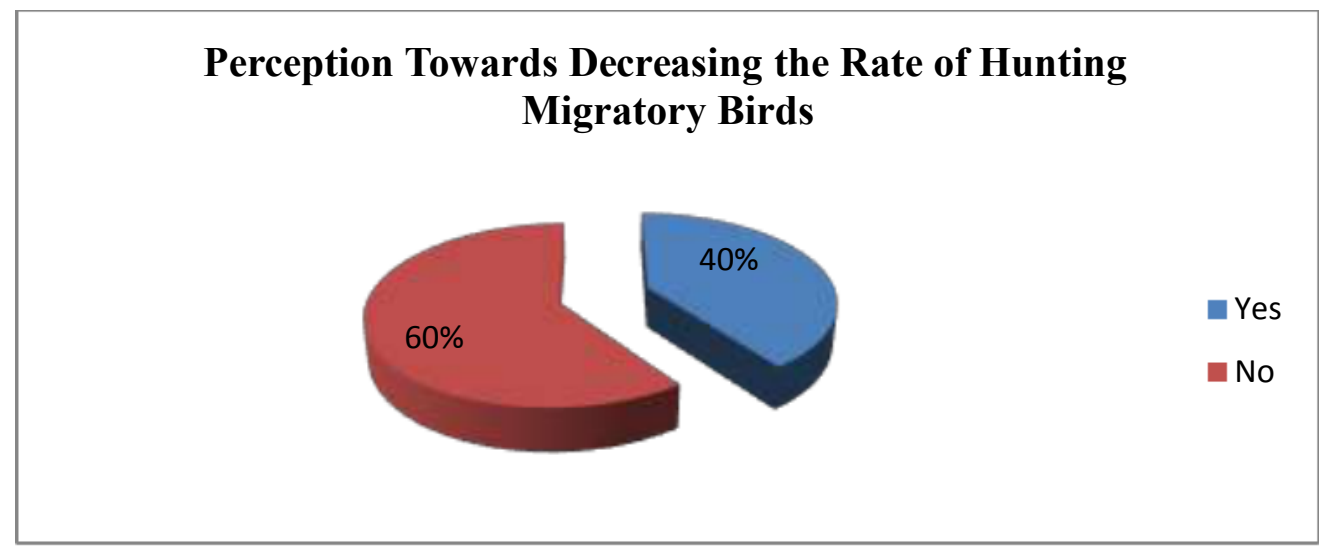

Figure 9

Source: Field Data

Above pie diagram shows, $60 \%$ respondents believe that the rate of hunting migratory birds in not decreasing though many initiatives have been taken by the government, NGOs and other stakeholders. Rest $40 \%$ respondents believe that the rate of hunting biodiversity is decreasing day by day.

\section{QUALITATIVE DATA ANALYSIS}

Thematic analysis is used in qualitative research and focused on examining themes within data. Thematic analysis is performed through the process of coding in six phases- Formalizing with data, generating initial code, searching for themes among code, reviewing themes, defining and naming themes, and producing final report. Thematic analysis is the process of identifying patterns or themes within qualitative data. 'It provides core skills that will be useful for conducting many other kinds of analysis' (p.78). A further advantage, particularly from the perspective of learning and teaching, is that it is a method rather than a methodology (Braun \& Clarke 2006; Clarke \& Braun, 2013).

The study topic "Role of Stakeholders in Preserving Biodiversity in Bangladesh: A study on Tanguar Haor" entails the findings that can be coded by the following themes:

\subsection{Causes of Loss of Biodiversity}

Bangladesh government has declared TanguarHaor as ecologically critical area and UNESCO declared it as world ramsar side. TanguarHaor is second samsara side of Bangladesh. The Haor is ecologically very diverse in Bangladesh. It contains 219 species birds, 98 species migratory birds, 121 species local birds, 19 species mammal, 141 species of fishes, 20 rare species of fishes (IUCN, 2013). Due to mismanagement and unawareness, biodiversity of TanguarHaor is on threat. The respondents explained the causes of loss of biodiversity of Tanguar Hoar from different angle.

\subsection{Illegal hunting, fishing, and cutting swamp forest}

At the time of interview, a government official working at office of the Deputy Commissioner, Sunamganj, stated:

"There are a number of reasons behind loss of biodiversity of TanguarHaor. It is true that illegal fishing, hunting migratory and local birds, cutting swamp forest is the general reasons of loss of biodiversity of TanguarHaor. But over crowd of tourists in Haor and their unconscious activities hamper the ecosystem of fishes, birds and other aquatic animals. Tourists spend the 
night in Tangua and torch towards migratory birds that seriously hamper the ecosystem of aquatic animals and migratory birds".

Alike an official of International Union for Conservation of Nature (IUCN) claimed:

"Fishing is the main profession of most the people living in TanguarHaor area. About 41.7 percent people subsist on the basis on fishing. They do not know the importance of the Haor and its biodiversity. Without fishing they do not have any option to earn money to maintain their family. As a result, despite restrictions from the government, the fisherman involved illegal fishing. Besides, deforestation or illegal cutting of swamp forest may be considered another reason of loss of biodiversity of TanguarHaor".

TanguarHaor is located under neighbouring country Meghalaya hill. An amount of silt soil has been mixed with rain water and waterfall from Meghalaya hill.

It seriously hampers the ecosystem of aquatic animals. The statements of the government bureaucrats and officials of the International Union for Conservation of Nature are roughly similar. According to them, illegal fishing, hunting migratory bird, cutting swamp forest, unconsciousness and unawareness are the main factors that contributed to loss of biodiversity. But the local government representative of Tahirpur Upazilla provide exceptional information that silt soil mixing with Haor water from Meghalaya hill contributed loss of aquatic animals' biodiversity. Many reasons identified behind destroying or cutting swamp forest like poverty, unawareness, lack of proper monitoring, lack of maintenance, increasing trace metal etc. These reasons play vital role in destroying swamp forest of TanguarHaor. An official of International Union for Conservation of Nature (IUCN) claimed:

"For the purpose of fish habitat restoration in the 'Beels' of TanguarHaor, the local peoples involve in cutting Heejol trees. Only for this purpose, thousands of Heejol tree have been cut in every year. Besides unawareness, lack of proper monitoring and increasing trace metal in Haor can be considered reasons behind destroying swamp forest".

A village farmer stated:

"We are highly dependent on nature. Sometimes trees are considered as barriers for cultivation of land. In that situation, farmers cut trees and make the land flat to cultivate corps".

A fisherman of TanguarHaor said:

"When crops are corrupted due to draws, flash flood and natural disaster, the people do not have any other option to survive. As a result, poor people involve cutting forest illegally. Indeed, poverty is the root cause of cutting swamp forest".

According to the statements of the most of respondents, poverty is the root cause of cutting swamp forest. By the policy of deforestation people try to convert forest into agricultural field for cultivation of crops. Besides, unawareness, lack of proper monitoring, lack of maintenance and increasing trace metal are marked as reasons behind destroying swamp forest.

\section{CORRUPTION}

Middle level officials of IUCN, Police, and ANSAR are accused of involving corruption. Local people and local government representatives claimed that ANSAR and police members take bribe from the fishermen and the forest cutters. As a result, fishermen involve in illegal fishing and wood cutter involve in deforestation. An official of International Union for Conservation of Nature (IUCN), stated:

"The ANSAR members, who are responsible for the TanguarHaor, accused of involving corruption and taking bribe for providing illegal opportunities to the corrupted people. They take bribe from people to have swamp forest cut and to have fish caught illegally at night."

A local level peoples 'representative noted: 
"The people involved in illegal activities like hunting migratory birds, catching fish, cutting swamp forest etc. They give bribe to the boatmen of executive magistrate to inform about the location of magistrate. Middle level officials of IUCN are the most corrupted persons. They put the money into their pocket instead of expending it on local people or cooperative society. In fine it is a looting project".

It is true they are accused of involving corruption but there is no proof to punish them. If anybody can show any evidence, punishing actions must be taken immediately. From above statements, it appears that combating corruption should be first priority to conserve biodiversity of TanguarHaor. Corrupted people do not care about conservation of nature rather conservation of money. Middle level officials of IUCN and ANSAR members involved mid-level corruption and provide facilities to the offenders to destroy natural resources.

\section{COLLABORATIVE ACTIONS TOWARDS PROTECTING BIODIVERSITY}

\subsection{Initiatives towards protecting migratory birds}

In every winter season thousands of migratory birds come to TanguarHaor from Cyberia and so other country. They stay in TanguarHaor in entire winter season and depend on the fisheries and other aquatic animals for the purpose of foods that live in the surface of the Haor. As migratory birds depend on fisheries and other aquatic animals, the aquatic animals are also benefited by the migratory birds' defecation and leftovers. Hunting migratory birds is great threat for biodiversity of TanguarHaor. Respondents are divided on the question of taken initiatives protecting hunting migratory birds.

A local government officer noted:

"To protect migratory birds and to prevent hunting bird district administration has taken initiatives. An executive magistrate is continuously on duty to protect birds and prevent illegal hunting. Besides executive magistrates, 14 ANSAR members are patrolling by boat to protect birds and to bring convicted persons under punishment. Very recently 6 offenders were sent to custody for hunting migratory bird".

A local level public representative opposed to the above statement and stated:

"There is no visible action taken by the district administration. Executive Magistrate who is responsible for protecting ecologically critical area of TanguarHaor is living 'Tekerghat' which is far away from the Haor area. Police and ANSAR members are very few to protect large area of TanguarHaor".

From above statements, it appears that some initiatives have been taken for the purpose of protecting migratory birds but these initiatives are not very effective. As executive magistrate lives in far away from Haor area, disciplinary action cannot be taken any time. Inadequate ANSAR members cannot guard large wetland area.

\subsection{INITIATIVES TOWARDS PROTECTING SWAMP FOREST}

Swamp forests have now become very thin due to cleaning, cutting and other anthropogenic activities. District Administration, International Union for Conservation of Nature (IUCN), peoples' representatives are responsible for protecting Swamp forest of TanguarHaor.

An official of International Union for Conservation of Nature (IUCN) claimed:

"First of all we tried to make people aware about the conservation of swamp forest. Nowadays a number of peoples are aware about the conservation of natural resources. In every village there established cooperative organizations. To preserve swamp forest more than two lac trees planted in Haor area. Recently more than sixty percent trees are visible". 
A local level public representative contradicts with IUCN official, and noted:

"International Union for Conservation of Nature and District Administration did not play appropriate role to preserve swamp forest of TanguarHaor. Maximum planted trees are not visible. There was large scale of corruption in terms of buying and planting trees. No person is punished due to illegal cutting of swamp forest. We (Peoples' Representatives) try to cooperate administration and IUCN to protect Tangua but they do not act properly".

Recently there is no initiative to protect swamp forest of Tanguar Haor. There is no project from government and NGOs to nurture the planted trees. International Union for conservation of Nature has planted more than two lac trees for forestation is TanguarHaor. There exists a large garden of 'Karach' trees in 'Hatirkacha' area. From the above statements of IUCN officials, local government representatives, it can be said that there is lack of coordination among these stakeholders. Currently government has no project to protect or nurture the swamp forest of TanguarHaor.

\subsection{INITIATIVES TOWARDS PROTECTING FISH SPECIES}

TanguarHaor contains more than half of the total fish species of Bangladesh. TanguarHaor is famous for biodiversity due to very diverse fish species of it. Illegal fishing, increasing trace metal, increasing silt soil from Meghalaya hampers the ecosystem of fish species and other aquatic animals.

An official of International Union for Conservation of Nature (IUCN) stated:

"To preserve rare fish species, restocking initiative has been taken by International Union for Conservation of Nature. Restocking through cloning, fish hatching has remarkable success to survive rare fish species".

A local government official claimed:

"Currently we have no economic allocation to maintain TanguarHaor. Despite many limitations we are trying to conserve biodiversity of TanguarHaor. Being a Deputy Secretary I myself visit Haor area frequently. To protect fish species and prevent illegal fishing, an executive magistrate is staying in that area 24 hours. The persons involved in illegal fishing are being punished under traditional laws".

The local level people's representative, are trying to make aware people and keep them away from illegal fishing in Haor. Union Parishad has arranged awareness meeting to build awareness against illegal fishing. International Union for Conservation of Nature (IUCN) initiated restocking of rare fish species for preservation of diverse fish species in TanguarHaor.

As government bureaucrats mentioned, an executive magistrate is assigned to protect illegal fishing in Haor area. Awareness building programs have been initiated by the peoples' representatives.

\section{ENVIRONMENT FRIENDLY EMPLOYMENT}

As most of the peoples are highly depended on nature, it is so tough to keep people away from the activities which act as root cause of loss of biodiversity of TanguarHaor. Local people and local government representatives have already demanded to government to open the door of environment friendly employment. Otherwise it would be toughest task to protect biodiversity of Tanguar Haor.

A local government official said:

"The government already has taken initiative to establish technical or vocational institute for the purpose of making people efficient to contribute national economy without harming natural resources. Besides a proposal is formulated by district administration to establish small and cottage industry by which local people can be self-reliant". 
A Village farmer expressed his melancholy:

"Fishing, cutting forest, driving engine based boat etc. are forbidden for local people. How can these poor people survive? As the people have no other options to survive, they involve in banned activities. It is the demand of Haor area people that environment friendly employment opportunity should be created by the government to combat illegal activities".

International Union for Conservation of Nature (IUCN) took some initiatives to make people self-reliant through various training such as- operating sewing machine, handicraft etc. but due to end of the tenure of the project it did not come to success. From the above statements of relevant stakeholders, it can be said that there is no opportunity of involving environment friendly employment instead of fishing, boatmanship of engine driven boat, wood cutting etc. District administration prepared a proposal of establishing small and cottage industry. The government also has declared to establish vocational educational institutions in Haor area. IUCN provided training to the people for making them self-reliant.

\section{ROLE OF INTERNATIONAL UNION FOR CONSERVATION OF NATURE (IUCN)}

International Union for Conservation of Nature (IUCN) established a collaborative management system for the purpose conservation, stabilisation and sustainable use of the natural resources of TanguarHaor. IUCN completed their project in three phases. But there is a debate about the success of big budgeted project done by IUCN.

An official of International Union for Conservation of Nature (IUCN), said:

"Actually we have conducted our projects in three phases. In first phase we tried to organize knowledge on TanguarHaor to provide necessary input for development phase and to select the communities to participate pilot co-management activities. In second Phase, IUCN established community based management system for the conservation and sustainable use of natural resources of TanguarHaor. Finally in third phase, co-management system is amalgamated and effective. The peoples have improved livelihoods and increased incomes and some of them become self-reliant".

A local government official claimed:

"It was looting project. There is no effectiveness of IUCN's project on local people. People still cut forest, involve illegal fishing activities. They form cooperative committees but the members of these committees are inactive. Some influential persons intended to loot allocations and budgets which was allocated for local community".

There were both negative and positive side of IUCN activities. They trained up some peoples who had actively participated on conservation process. They planted trees and restocked fisheries. IUCN also conducted some research which will help our further initiatives. In the contrast, the trained people involved in looting and illegal fishing, cutting swamp forest in night. They played their role as spoiler instead of conserver. IUCN established 40 Village Development Cooperative Society. These cooperative societies actively participated in conservation of biodiversity. A central cooperative society named as TanguarHaor Central Village Development Cooperative Society consists of forty members- each from every cooperative society. Cooperative societies had done awareness programs. Cooperative societies provided community guard, fund for maintaining guards. About 40 community guards worked for protecting swamp forest and illegal fishing. From above statements, it appears that International Union for Conservation of Nature (IUCN) has contributed to preserve biodiversity of TanguarHaor. They have conducted their project in three phases. IUCN conducted research on TanguarHaor that will help for further initiatives or further research. For preserving rare fish species IUCN took initiative of restocking rare fish species. Forestation initiative also has been 
taken by IUCN. They established Village Development Cooperative Societies for the purpose of making people self-reliant. Though a number of commendable initiatives, IUCN has been criticised for some irregularities. Local government representatives and government agencies claimed that middle level officials of IUCN involved in corruption. Forestation and restocking of rare fish species is eye washing initiative. Besides, village development cooperative society has been criticised for corruption and mismanagement.

\section{PUBLIC AWARENESS}

Awareness building is one of the most important preconditions to enact people in conserving biodiversity of TanguarHaor. Most of the peoples are unaware about the consequences of the misuse of natural resource of TanguarHaor. International Union for Conservation of Nature (IUCN) attempted to make people aware through arranging various programs. Besides IUCN, district administration and local government representatives has also taken some initiatives to make people aware.

One of villagers mentioned about awareness building initiatives, as:

"IUCN makes us aware about the importance of biodiversity and proper utilization of natural resources through various programs such as village meeting, awareness meeting, awareness campaign, drama showing, documentary showing etc."

A local government official said:

"Frequently district administration arranges some meetings and seminars for the purpose of making people aware about importance of TanguarHaor and its resources. Few days ago district administration organised a seminar on 'Unnoyon Bhabona' (Development Thought)".

Above statements appear that International Union for Conservation of Nature (IUCN) arranged some awareness building programs like village meeting, awareness meeting, awareness campaign, drama showing, documentary showing etc. Besides IUCN, district administration and local government representatives initiated some program for awareness building. Since lots of awareness building programs, people still unaware about the conservation of biodiversity of TanguarHaor.

\subsection{Coordination of government, NGOs and peoples' representatives}

Government bodies, local government representatives and Non-Government Organizations are the important stakeholders of TanguarHaor. They usually play vital role in protecting aquatic animals and organisms from internal and external threats. When IUCN conducted their project in Tanguar Haor, it was observed that there was lack of coordination among government officials, local government representatives and IUCN officials. Respondents from one group complain against another

One peoples 'representative claimed:

"International Union for Conservation of Nature (IUCN) has been conducted a project in three tenures for ten years but did not include us (Local government Representatives) for a single time. Personally I did not get any invitation from IUCN. Besides district administration do not coordinate with us in terms of financing, supporting and other functions".

An official of IUCN argued:

"Every Village Development Cooperative Society has been doing their job by the direct or indirect direction of Union Parishad representatives. IUCN always try to involve peoples' representatives in cooperative activities".

There is found discrepancy among government agencies, non-government organizations and local government representatives. IUCN conducted their project without involving local government representatives and government agencies. In the same way, government agencies 
did not coordinate with peoples' representatives in executing any policy or project. Coordination among these stakeholders is necessary for protecting biodiversity of TanguarHaor.

\section{FURTHER ACTIONS TO PROMOTE BIODIVERSITY CONSERVATION}

\subsection{Accountability and transparency of stakeholders}

Most of the respondents believe that accountability and transparency of relevant stakeholders are not ensured. Especially International Union for Conservation of Nature (IUCN) conducted the project of TK 100 crore ( 1 billion) budget but there is a question that whether they expend the budget in transparent manner. Although IUCN thinks that both internal and external accountability mechanism has been ensured in this project where internal accountability ensured through cooperative society. However, there is a big controversy about this.

One Peoples' representative said:

"There was no accountability mechanism to make IUCN officials accountable. The way of expending money was not in transparent manner as far I know. As we are peoples' representatives, peoples complain to us about the corruption IUCN officials in collaboration with local influential persons".

A local level government official noted:

"We (District Administration) are not responsible to make IUCN officials accountable. Ministry of Forest and Environment Affairs ministry can ensure accountability of IUCN. But accountability of administrative officials and police personnel is ensured. The executive magistrate has to report to the office of the deputy commissioner what initiatives he takes and why".

\subsection{Haor based tourism industry and conservation of biodiversity}

Recently tourists have shown great interest towards TanguarHaor. In every year, thousands of tourists visit the Haor and enjoy the beauty of country's second RAMSAR site. Though over crowd of tourists hamper the natural ecosystem of aquatic animals and migratory birds, the stakeholders want to spread Haor based tourism and to conserve the biodiversity of TanguarHaor simultaneously.

A government official said:

"TanguarHaor based tourism industry can be another important source of revenue of the government. It can help the local people to be self-reliant. Local infrastructure like-Road, Calvert, Transportation, Rest House, Guest House should be established well planned. Alongside initiatives should be taken to protect biodiversity of TanguarHaor. Engine driven boat should be forbidden, specific area should be highly protected and restricted, and watch towers should be built to enjoy natural beauty of TanguarHaor."

One Peoples' Representative stated:

"If tourism industry spreads in TanguarHaor, the local people will be benefited economically. It will help the people to survive without hampering the Haor and aquatic animals. Through tourism industry, employment opportunity will be created and people will not be involved in illegal fishing and cutting swamp forest".

Most of the respondents believe that Haor based tourism industry can be spread and biodiversity of TanguarHaor can be conserved simultaneously. By forbidding engine driven boat, restricting specific areas, building watch towers to enjoy natural beauty and appointing more ANSAR and police personnel, biodiversity of TanguarHaor can be preserved. For the 
purpose of spreading Haor based tourism industry, local infrastructure like -road-culvert, transportation, rest house, guest house etc. should be developed.

\subsection{Increased number of appointed ANSAR members}

TanguarHaor expands with the area of 9,727 hectares but there are only 14 ANSAR members to protect the huge wetland area. Only 14 ANSAR members are divided into 4 ANSAR camp. It is too tough to protect large wetland area from the enemy of nature.

A government official said:

"It is impossible to protect 9727 hectares wetland area by 14 ANSAR members. To maintain TanguarHaor efficiently there need at least 100 ANSAR members needed who will perform their duty shift wise".

There are lots of limitations in maintaining TanguarHaor. Only 14 ANSAR members have been performing their duty for long time. It is notable that The ANSAR members have not been getting salaries since May 2018.

\subsection{Implement disciplinary actions without any Interference}

In the time of punishing offenders who are involved in destroying natural resources of TanguarHaor, peoples 'representatives often create pressure upon administrative authorities to release offenders.

A local government official claimed:

"Some local government representatives cooperate in taking disciplinary action but some representatives try to interfere or create pressure in taking disciplinary action. As a result, offenders get release and involved in illegal activities".

By denying the above allegation, one peoples' representative noted:

"As a local government representative, we can ask any question about any administrative action. The administrative authorities do not like to be accountable to the mass people".

From above statements, it appears that there is lack of coordination and cooperation between administrative authorities and local government representatives. As local government representatives need vote of mass people, they sometimes try to keep the voters safe from punishment. Hence, the administration should have the ability to take actions against the offenders of violating biodiversity and environment related discipline without any pressure from peoples' representatives.

\section{LIMITATIONS OF THE STUDY}

There are some limitations, the researcher had to face. Due to there is constraint of time, there were few difficulties to conduct study. It was difficult to convince the respondent and make prepared for interview as most of the respondents hold top position of the government as well as the region. So, interviewing took time, which was harder to get from the older and female people. Some respondents were politically biased. As research area was in TanguarHaor area, it was very costly to collect data by attending researcher physically. Although, there were some limitations, the researcher has tried his best to make the research better.

\section{CONCLUDING REMARKS WITH POLICY IMPLICATIONS}

The ecological system surrounding the TanguarHaor provides livelihood to some 77,000 population spread over 88 villages (Census of TH, 2007). For these people, Haor is a source of them income, employment as well as their livelihood. It provides rice and fish to them, the major two sources of income earning for the households. After conducting research, it is clear that ecosystem and biodiversity of TanguarHaor is in danger for so many reasons. Since 1990s 
the government took different initiatives for protecting TanguarHaor. After two or three decades, the country's second ramsar site Tanguar Haor is still under great threat in terms of loss of biodiversity and ecosystem. There is lack of coordination among government agencies, local government representatives and NGOs. Ministry of Forestry and Environment Affairs do not appropriately coordinate with district administration. To preserve biodiversity of TanguarHaor, management system should be developed at first. A comprehensive management plan must be developed for TanguarHaor that can ensure active participation of relevant stakeholders. Spreading tourism industry with preserving biodiversity of TanguarHaor will be great challenge for government. The government should appoint adequate manpower to manage tourism industry. Besides, proper guidelines should be developed for tourists and local people. To keep local people away from the illegal activities in Haor area, environment friendly employment opportunity should be created urgently. At last it can be said that the countries' important wetland area is in danger. The following necessary measures should be introduced to conserve one of the most diverse wetland (TanguarHaor) of Bangladesh.

- Comprehensive management plan of Tanguar Haor should be developed so that coordination among peoples' representatives, NGOs and government officials can be ensured.

- Vocational educational institution should be established by which people can be transformed into human resources and they can involve in those occupations that will not hamper natural ecosystem of aquatic animals and migratory birds.

- To keep the poor people away from the illegal activities in Haor area, environment friendly employment opportunity should be created. For this purpose, government can provide small loan without interest or with minimum interest to the peoples for establishing small and cottage industry, farming etc.

- Proper guideline should be formulated for the tourists so that they can enjoy natural beauty without hampering biodiversity of Tanguar Haor. Some measures should be taken to protect biodiversity of Tanguar Haor and to promote tourism based on Tanguar Haor simultaneously.

- Corrupted government officials, NGOs officials, ANSARs and police personnel must be punished. Zero tolerance policy should be adopted against corruption. To combat corruption, regulatory bodies should monitor closely the activities and role of the relevant stakeholders.

\section{REFERENCES}

[1] Alam, A.B.M.S., Chowdhury, M.S.M., \& Sobhan, I, Biodiversity of Tanguar Haor: A Ramsar Site of Bangladesh, Wildlife (Amphibians, Reptiles, Birds and Mammals). IUCN (International Union for Conservation of Nature), Bangladesh Country Office, Banani, Dhaka. Volume 1, 2012.

[2] Aliaga, M., \& Gunderson, B, Interactive statistics. New Jersey: Prentice Hall, United States, 2002

[3] Alston, M., \& Bowles, W, Research for social workers: An introduction to methods. Psychology Press, Allen \& Unwin, 2003

[4] Ahmed, M, Ujja Fishing. Protection and management report on fish migration and management in Tanguar Haor. TARA (Technical Assistance for Rural Advancement), IUCN, SDC (Swiss Agency for Development and Cooperation), (2008), pp. 1-30.

[5] Ariyabandhu, M. M., \& Wackramasinghe, W. M, Gender dimension in disaster management: a guide for South Asia, Practical Action, Sri Lanka, 2005

[6] Regina, B., \& Nabi, B, Physico-chemical spectrum of the Bhavani River water collected from the Kalinga Rayan Dam, Tamilnadu. Indian Journal of Environment and Eco plan, 7(3): 2003, pp 633-636.

[7] Babbie, E. R. The Practice of Social Research. Nelson Education, 2015 
[8] Bavenger, K., Dutta, A. K., Eid, A. T., \& Shirin, M, Tanguar Haor wetland biodiversity conservation project: an appraisal. NINA NIKU Project Report, 16, 2001, pp 1-37.

[9] Bloom \& Crabtree, The qualitative research interview. Blackwell publishing, New Jersey, United States, 2006

[10] Brouwer, R., Akter, S., Brander, L., \& Haque, E, Socio-economic vulnerability and adaptation to environmental risk: A case study of climate change and flooding in Bangladesh. Risk anal, 27 (2), 2007, pp 313-26.

[11] Chakraborty, T. R, Management of haors, baors, and beels in Bangladesh. Lessons for Lake Basin Management, 1, 15, 2009

[12] Chowdhury, M. H. K., \& Hussain, A., Aridity and drought conditions of Bangladesh.Tropical droughts (meteorological aspects and implications for agriculture). Journal of WMO Program on Research in Tropical Meteorology, 1981, pp: 73-80.

[13] Creswell, J. W, Qualitative inquiry and research design: Choosing among five traditions. Thousand Oaks, CA: Sage Publications, London, New Delhi,1998

[14] Khan, F. H, Geology of Bangladesh. Dhaka: The University Press Limited, 1991

[15] IUCN Bangladesh, Tanguar Haor management plan framework and guidelines. IUCN (International Union for Conservation of Nature), Bangladesh Country Office, Banani, Dhaka, 2015

[16] Haque, E., \& Kazal, H, Rich resources, poor people: the paradox of livingTanguar Haor. Last consulted on 12 March (2019), 2008

[17] Haque, M. I., \& Basak, R, Land cover change detection using GIS and remote sensing techniques: A spatio-temporal study on Tanguar Haor, Sunamganj, Bangladesh. The Egyptian Journal of Remote Sensing and Space Science, 20(2), 2017, pp 251-263.

[18] Islam, S. N, Threatened wetlands and ecologically sensitive ecosystems management in Bangladesh. Frontiers of Earth Science in China, 4(4), 2010, pp 438-448.

[19] Khan, M. N. H., Mia, M. Y., \& Hossain, M. R, Impacts of flood on crop production in Haor areas of two Upazillas in Kishoregonj. Journal of Environmental Science and Natural Resources, 5(1), 2012, pp 193-198.

[20] Mamun, S. A., Roy, S., Rahaman, M. S., Jahan, M., \& Islam, M. S, Status of Fisheries Resources and Water Quality of Tanguar Haor. Journal of Environmental Science and Natural Resources, 6(1), 2013, pp 103-106.

[21] Mazumder, A, Community based sustainable management of Tanguar Haor Project. University press limited: Dhaka, 2014

[22] Mondal, P., Glaser, M., Nishat, A., \& Breckwoldt, a, Co-management approach on fisher group: A case study on Ramsar site, Tanguar Haor in Bangladesh. Bangladesh Journal of Fisheries Research, 14(1-2), 2010, pp 103-114.

[23] Nayeem, A., Majumder, D. A. K., \& Hossain, M.S, Impact of Flash Flood on Agriculture Land in Tanguar Haor Basin. International Journal of Research in Environmental Science, 3(4), 2017, pp 42-45.

[24] P. S. Sridhar and Bhoopathy Bhaskaran, A Study of Marine Biodiversity: Macrobenthos In Arabian Gulf, International Journal of Mechanical Engineering and Technology, 6(10), 2015, pp. 55-59.

[25] Polit, D., \& Hungler, B, Nursing Research: Principle and Method. (6th ed.), Philadelphia: Lippincott Company, (2011), P.P. 416-417. 
[26] Rahaman, M. M., Sajib, K. I., \& Alam, I, Impacts of Climate Change on the Livelihoods of the People in Tanguar Haor, Bangladesh, Journal of Water Resource Engineering and Management , 3(1),2016,pp 1 -9.

[27] Rahman, M. M., Sharker, M. R., Sumi, K. R., Alam, M. A., \& Hossen, M. S, Landmarkbased morphometric and meristic variations of stinging catfish, Heteropneustes fossilis (Bloch) among three isolated stocks, the Old Brahmaputra river and the Tanguar haor and a hatchery. International Journal of Fisheries and Aquatic Studies, 1(3), 2014, pp 163-170.

[28] Salauddin, M., \& Islam A. K. M. S, Identification of land cover changes of Haor areaof Bangladesh. Paper presented in 3rd International Conference on Water \& Flood Management (ICWFM), Institute of Water and Flood Management, BUET: Dhaka, Bangladesh 2011, Page 1-7.

[29] Singh, P. P, Exploring biodiversity and climate change benefits of community-based forest management. Global Environmental Change, 18(3), 2008, pp 468-478.

[30] Oviedo, G., Van Griethuysen, P., \& Larsen, P. B, Poverty, equity and rights in conservation: technical paper and case studies. Graduate Institute of Development Studies, 2006

[31] Uddin, M., Miah, M., Afrad, M., Mehraj, H., \& Mandal, M, Land use change and its impact on ecosystem services, livelihood in Tanguar haor wetland of Bangladesh. Scientia Agriculturae, 12(2), 2015, pp 78-88. 